ISSN 1392-3196 / e-ISSN 2335-8947

Zemdirbyste-Agriculture, vol. 107, No. 4 (2020), p. 301-308

DOI $10.13080 /$ z-a.2020.107.038

\title{
Effects of tillage methods on senescence and grain filling characteristics of Tartary buckwheat
}

\author{
Xinghui WU, Yu ZHANG, Peiyun HE, Xiaoyan HUANG, Kaifeng HUANG \\ Guizhou Normal University, Research Center of Buckwheat Industry Technology \\ Guiyang 550001, China \\ E-mail: hkf1979@163.com
}

\begin{abstract}
A field experiment was conducted on a yellow loam in 2017 and 2018. The study used a Tartary buckwheat (Fagopyrum tataricum L.) cultivar 'Jinqiao 2' to determine the effects of no-tillage, conventional tillage and deep tillage on the senescence and grain filling characteristics. The tillage methods were investigated based on the changes in buckwheat grain filling dynamics, root morphology and physiology, photosynthetic pigment content, antioxidant enzyme activity, malondialdehyde (MDA) content and yield formation. The initial growth power, maximum grain filling rate, the values of root morphological characteristics, root activity, photosynthetic pigment contents and antioxidant enzyme activities were the highest under deep tillage. The MDA content was the highest under no-tillage. The agronomic characters and yield formation indexes of Tartary buckwheat were better under deep tillage.

The results of this study showed that deep tillage promoted the grain filling of Tartary buckwheat, delayed the senescence and increased the final yield.
\end{abstract}

Key words: grain filling, early senescence, root morphology, deep tillage, yield.

\section{Introduction}

Buckwheat belongs to the genus Fagopyrum Mill. The multispecies of Fagopyrum can be classified into two types: common buckwheat (Fagopyrum esculentum Moench) and Tartary buckwheat (Fagopyrum tataricum L.) (Takuya et al., 2019). Tartary buckwheat is extensively distributed in the world and is grown in Russia, China, France, Pakistan, Japan, Poland and other countries (Zhang et al., 2020). Tartary buckwheat has remarkable functions of lowering blood sugar, blood pressure, blood lipid and antitumor given its rich content of flavonoids, D-chiral inositol and other substances (Dziedzic et al., 2012; Ahmed et al., 2014; Górecka et al., 2014; Giménez-Bastida et al., 2015; Žvikas et al., 2016; Podolska et al., 2019). Therefore, it is often used to treat diseases (Kalinova, Dadakova, 2013; Zhang et al., 2019; Kreft et al., 2020) and is a food crop with great health benefits (Guglielmini et al., 2019). However, at present, the yield of Tartary buckwheat in China is relatively low at approximately $1500-2400 \mathrm{~kg} \mathrm{ha}^{-1}$ (Song et al., 2014). Improvement of the yield of Tartary buckwheat is important to promote the development of buckwheat industry.

On the scale of crop growth stages, grain filling is the final stage of yield formation, which directly affects the final yield of crops (Arduini et al., 2016; Panda et al., 2018); simultaneously, grain filling is a period when crops begin to senescence. Senescence is an inevitable physiological phenomenon in a crop growth cycle. It is a process in which plant tissues or organs move toward functional decline or death. If the crop senescence is rapid, the physiological and biochemical metabolisms of the entire plant change, photosynthesis is seriously reduced, assimilates are insufficient, and grain filling is affected (Kong et al., 2013). Studies have found that early senescence can reduce the plumpness of rice and wheat grain, thereby resulting in a yield loss of more than $20 \%$ (Zhang et al., 1998). Therefore, delaying crop senescence has become an important scientific problem of high-yield crop cultivation and is crucial for promoting grain filling and increasing the final.

Tillage can improve the water and heat conditions and other physical and chemical properties of soil. Moreover, a suitable tillage method can promote the development of root system, increase its activity, delay the senescence of aboveground and underground organs and increase yield (Linh et al., 2015). We hypothesize that tillage methods affect the formation of final yield by influencing grain filling characteristics and senescence. In the current study, cultivar 'Jinqiao 2' was used to investigate the effects of tillage methods on the senescence and grain filling characteristics of Tartary buckwheat. Thus, the objectives of this study were:

Please use the following format when citing the article:

Wu X., Zhang Y., He P., Huang X., Huang K. 2020. Effects of tillage methods on senescence and grain filling characteristics of Tartary buckwheat. Zemdirbyste-Agriculture, 107 (4): 301-308. DOI 10.13080/z-a.2020.107.038 
(1) to clarify the mechanism of effects of tillage on the grain filling characteristics and senescence, and (2) to provide a theoretical basis for cultivating high-yielding Tartary buckwheat.

\section{Materials and methods}

Plant material and growth. Tartary buckwheat (Fagopyrum tataricum L.) cultivar 'Jinqiao 2' used in this experiment was obtained from the Research Center of Buckwheat Industry Technology of Guizhou Normal University. The experiment was conducted in cement pools at Huangnitang's Cultivation Experiment Station of the Key Laboratory for Cultivation Physiology and Application of Buckwheat of Guizhou (922 m, 27 $05^{\prime}$ $\mathrm{N}, 105^{\circ} 71^{\prime}$ E), Bijie City, Guizhou Province, China, during the Tartary buckwheat growing season (August to November) of 2017 and repeated in 2018.

The experimental soil was yellow loam with $34.45 \mathrm{~g} \mathrm{~kg}^{-1}$ organic matter, $49.16 \mathrm{~g} \mathrm{~kg}^{-1}$ available nitrogen, $323.33 \mathrm{mg} \mathrm{kg}$-1 available phosphorus, $130.22 \mathrm{mg} \mathrm{kg}^{-1}$ available potassium and a $\mathrm{pH}$ of 5.76 . Tartary buckwheat was cultivated in cement pools with an area for each test plot measuring $2 \times 10 \times 0.3 \mathrm{~m}$, and three tillage treatments were implemented. The depths were $4-5,10-15$ and $20-25 \mathrm{~cm}$ for the no-tillage (NT), conventional tillage (CT) and deep tillage (DT) treatments, respectively. The optimum application rates of nitrogenous, phosphate and potassium fertilizers were 100, 69 and $5.1 \mathrm{~kg} \mathrm{ha}^{-1}$, respectively (Song et al., 2014). The three fertilizers were mixed and applied as basic fertilizer once during the entire growth period.

The seeds were sown in cement pools on August 1, 2017 and August 5, 2018. The row spacing was $33 \mathrm{~cm}$, and the seeding rate was $52.5 \mathrm{~g} \mathrm{plot}^{-1}$. Through thinning out or supplementing seedlings at seedling stage a plants density of approximately $900-1000$ plants per plot was maintained. The Tartary buckwheat seeds (70\% of seeds turned brown yellow) were harvested on November 22 in 2017 and on November 28 in 2018. All treatments were repeated thrice, and there were nine cement pools in total. Monthly average temperature from August to November in 2017 was $20.3^{\circ} \mathrm{C}$, and monthly average sunshine was $125.6 \mathrm{~h}$, and in 2018 it was $19.9^{\circ} \mathrm{C}$ and $116.2 \mathrm{~h}$, respectively. During the grain filling period of Tartary buckwheat, artificial irrigation was carried out according to the conventional principle of "extreme drought and thoroughly irrigated", and the other periods depend on natural precipitation.

Sample preparation. At the beginning of the flowering period, approximately 1000-1500 flowers that bloomed on the same day and on the same part of Tartary buckwheat were marked in each pool, and the marked flowers were sampled every 7 days from 7 days after flowering to maturation to determine the grain filling. Approximately 10 plants from each plot with uniform growth were sampled at the seedling, flowering, grain filling and maturity periods. The roots were washed to remove the soil and sheared and mixed after drying to determine the root morphology. Approximately 20 Tartary buckwheat plants with similar growth were cautiously removed to measure their root activity, chlorophyll and carotenoid contents, antioxidant enzyme activity and malondialdehyde (MDA) content in the leaves (the $4^{\text {th }}$ node at the top of the main stem).

Determination of simulation of grain filling. A 1000-grain weight was determined from 10 plants randomly sampled from each plot (thrice the average replicate, with a relative error of $<0.5 \mathrm{~g}$ for each replicate). Based on the studies of Liang et al. (2016) and Wang etal. (2017), Richards' equation was used to describe the grain filling:

$$
W=A /\left(1+B \mathrm{e}^{-K t}\right)^{1 / N},
$$

where $W$ is the weight of buckwheat seeds in each period $(\mathrm{g}), A$ - the final growth value, $B-$ the initial value parameter, $e$ - constant, $K$ - the growth rate parameter, $t$ - the time after flowering (the day of flowering is $0, \mathrm{~d}), N$ - the shape parameter; $R^{2}-$ the ratio of $W$ to the total sum of squares of $t$, i.e. the judgment coefficient, indicating its degree of cooperation.

Determination of root morphology and root activity. A root scan analysis system GXY-A (Zhejiang Tuopu Instrument Co. Ltd., China) was used to determine the root length, surface area, volume and mean diameter of Tartary buckwheat. Root activity was determined through the 2,3,5-triphenyl-tetrazolium chloride (TTC) method (Zhang, Qu, 2003).

Determination of chlorophyll and carotenoid contents. The contents of chlorophyll $a$, chlorophyll $b$, total chlorophyll (chlorophyll $a+$ chlorophyll $b$ ) and carotenoids in the leaves of Tartary buckwheat were determined through colorimetric method (Zhang, Qu, 2003).

Determination of antioxidant enzyme activity and $M D A$ content. Superoxide dismutase (SOD) activity was determined through nitro-blue tetrazolium (NBT) method, and peroxidase (POD) activity was measured using an ultraviolet spectrophotometer (Zhejiang Tuopu Instrument Co. Ltd.); MDA was determined through thiobarbituric acid (TBA) method (Zhang, Qu, 2003).

Determination of agronomic characters and yield. The Tartary buckwheat plant height, main stem node number, main stem branch number, number of seeds per plant, grain weight per plant and 1000-grain weight were measured based on the method proposed by Wang et al. (2020). The yield of each treatment was determined at maturity and converted into $\mathrm{kg}$ per ha.

Statistical analysis. The collected data were statistically analysed through software package SPSS, version 17.0 (SPSS Inc., USA) using single-factor analysis of variance (ANOVA), and treatment means were compared using the least significant difference at the 0.05 probability level.

\section{Results}

Grain weight gain at the filling stage. With the increase in days after flowering, the dry weight (DW) of 1000 grains of Tartary buckwheat initially increased rapidly and then slowly (Table 1 ). The 1000-grain DW was higher under DT than under NT and CT, and the difference reached a significant level at 35 days after flowering.

Simulation of grain filling. According to Richards' equation, the final growth value $(A)$ of DT was higher than NT and CT (Table 2). The shape parameter $(N)$ values of Tartary buckwheat were all less than 1 
Table 1. The grain dry weight (g) of Tartary buckwheat at days after anthesis

\begin{tabular}{cllllll}
\hline \multirow{2}{*}{ Year } & \multicolumn{1}{c}{ Tillage method } & 7 days & 14 days & 21 days & 28 days & 35 days \\
\hline \multirow{2}{*}{2017} & no-tillage (NT) & $4.98 \mathrm{a}$ & $13.99 \mathrm{a}$ & $18.34 \mathrm{a}$ & $20.65 \mathrm{a}$ & $21.13 \mathrm{~b}$ \\
& conventional tillage (CT) & $5.87 \mathrm{a}$ & $13.86 \mathrm{a}$ & $18.42 \mathrm{a}$ & $20.42 \mathrm{a}$ & $23.02 \mathrm{~b}$ \\
& deep tillage (DT) & $5.05 \mathrm{a}$ & $13.99 \mathrm{a}$ & $18.67 \mathrm{a}$ & $23.08 \mathrm{a}$ & $26.58 \mathrm{a}$ \\
\hline \multirow{2}{*}{2018} & no-tillage (NT) & $4.20 \mathrm{a}$ & $14.29 \mathrm{~b}$ & $18.22 \mathrm{a}$ & $20.09 \mathrm{a}$ & $21.41 \mathrm{~b}$ \\
& conventional tillage (CT) & $4.31 \mathrm{a}$ & $14.54 \mathrm{~b}$ & $18.41 \mathrm{a}$ & $20.24 \mathrm{a}$ & $21.54 \mathrm{ab}$ \\
& deep tillage (DT) & $4.15 \mathrm{a}$ & $15.59 \mathrm{a}$ & $18.69 \mathrm{a}$ & $21.04 \mathrm{a}$ & $22.95 \mathrm{a}$ \\
\hline
\end{tabular}

Significant at $P<0.05$

Table 2. Richards' equation parameters of Tartary buckwheat grain filling

\begin{tabular}{|c|c|c|c|c|c|c|c|c|c|c|}
\hline Year & Tillage method & $\begin{array}{c}\text { Final growth } \\
\text { value } \\
(A)\end{array}$ & $\begin{array}{c}\text { Initial value } \\
\text { parameter } \\
\text { (B) }\end{array}$ & $\begin{array}{c}\text { Growth rate } \\
\text { parameter } \\
\qquad(K)\end{array}$ & $\begin{array}{c}\text { Shape } \\
\text { parameter } \\
(N)\end{array}$ & $R^{2}$ & $R_{0}$ & $\begin{array}{c}G \max \\
100 \mathrm{~g} \mathrm{~d}^{-1}\end{array}$ & $\begin{array}{c}W \max G \\
\mathrm{~g}\end{array}$ & $\begin{array}{c}I \\
\%\end{array}$ \\
\hline \multirow{3}{*}{2017} & no-tillage (NT) & 2.412 & 0.907 & 0.0285 & 0.001113 & 0.971 & 25.909 & 0.025 & 0.888 & 36.816 \\
\hline & $\begin{array}{l}\text { conventional } \\
\text { tillage (CT) }\end{array}$ & 2.691 & 0.916 & 0.0395 & 0.001114 & 0.990 & 35.909 & 0.039 & 0.991 & 36.826 \\
\hline & deep tillage (DT) & 3.223 & 0.914 & 0.0552 & 0.001133 & 0.982 & 50.182 & 0.065 & 1.186 & 36.798 \\
\hline \multirow{3}{*}{2018} & no-tillage (NT) & 2.331 & 0.879 & 0.0214 & 0.001139 & 0.976 & 19.455 & 0.018 & 0.858 & 36.808 \\
\hline & $\begin{array}{l}\text { conventional } \\
\text { tillage (CT) }\end{array}$ & 2.163 & 0.938 & 0.0251 & 0.001113 & 0.983 & 22.818 & 0.020 & 0.796 & 36.801 \\
\hline & deep tillage (DT) & 2.451 & 0.934 & 0.0346 & 0.001130 & 0.993 & 31.455 & 0.031 & 0.902 & 36.801 \\
\hline
\end{tabular}

$R^{2}$ - the ratio of $W$ to the total sum of squares of $t, R_{0}$ - the initial growth power, $G$ max - the maximum grain filling rate, $W \max G$ - the growth at the day with maximum grain filling rate, $I$ - the final grain dry weight at harvest

under different tillage methods. No significant difference was observed in the shape parameter $(N)$ values among the tillage methods. The initial growth power $\left(R_{0}\right)$, maximum grain filling rate $(G \max )$ and growth at the day with maximum grain filling rate $(W \max G)$ were the highest under DT. No significant difference was observed in the ratio of the grain weight at the Gmax to the final grain dry weight at harvest $(I)$ among the tillage methods, and the lowest $I$ value was observed under DT. The law of change in 2017 and in 2018 was similar.

Root morphology. In 2017, the total root length, root surface area and average root diameter of Tartary buckwheat at the seedling stage were the largest under DT and CT and the smallest in NT (Table 3).

Table 3. The effect of tillage methods on root morphology of Tartary buckwheat

\begin{tabular}{|c|c|c|c|c|c|c|c|c|c|}
\hline \multirow[b]{2}{*}{$\begin{array}{l}\text { Root } \\
\text { indices }\end{array}$} & \multirow[b]{2}{*}{ Tillage method } & \multicolumn{4}{|c|}{2017} & \multicolumn{4}{|c|}{2018} \\
\hline & & $\begin{array}{l}\text { seedling } \\
\text { stage }\end{array}$ & anthesis & $\begin{array}{l}\text { grain filling } \\
\text { stage }\end{array}$ & $\begin{array}{l}\text { mature } \\
\text { stage }\end{array}$ & $\begin{array}{l}\text { seedling } \\
\text { stage }\end{array}$ & anthesis & $\begin{array}{l}\text { grain } \\
\text { filling } \\
\text { stage }\end{array}$ & $\begin{array}{l}\text { mature } \\
\text { stage }\end{array}$ \\
\hline \multirow{3}{*}{$\begin{array}{l}\text { Length } \\
\mathrm{cm}\end{array}$} & no-tillage (NT) & $33.291 \mathrm{~b}$ & $83.183 \mathrm{c}$ & $241.109 \mathrm{a}$ & $143.499 \mathrm{~b}$ & $31.180 \mathrm{a}$ & $61.648 \mathrm{~b}$ & $245.170 \mathrm{~b}$ & $140.159 \mathrm{~b}$ \\
\hline & $\begin{array}{l}\text { conventional } \\
\text { tillage (CT) }\end{array}$ & $39.794 \mathrm{a}$ & $97.641 \mathrm{~b}$ & $155.275 \mathrm{~b}$ & $125.451 \mathrm{c}$ & $27.760 \mathrm{~b}$ & $123.487 \mathrm{a}$ & $269.256 \mathrm{a}$ & $137.460 \mathrm{c}$ \\
\hline & deep tillage (DT) & $41.819 \mathrm{a}$ & $156.262 \mathrm{a}$ & $243.421 \mathrm{a}$ & $164.419 \mathrm{a}$ & $32.305 \mathrm{a}$ & $154.148 \mathrm{a}$ & $269.753 \mathrm{a}$ & $167.414 \mathrm{a}$ \\
\hline \multirow{3}{*}{$\begin{array}{l}\text { Surface } \\
\text { area } \\
\mathrm{cm}^{2}\end{array}$} & no-tillage (NT) & $5.876 \mathrm{~b}$ & $20.626 \mathrm{~b}$ & $58.226 \mathrm{a}$ & $31.392 \mathrm{a}$ & $4.017 \mathrm{~b}$ & $13.494 \mathrm{~b}$ & $43.665 \mathrm{c}$ & $30.923 \mathrm{~b}$ \\
\hline & $\begin{array}{l}\text { conventional } \\
\text { tillage }(\mathrm{CT})\end{array}$ & $6.844 \mathrm{a}$ & $25.821 \mathrm{a}$ & $42.472 \mathrm{~b}$ & $32.641 \mathrm{a}$ & $4.117 \mathrm{~b}$ & $31.472 \mathrm{a}$ & $56.397 \mathrm{~b}$ & $37.776 \mathrm{a}$ \\
\hline & deep tillage (DT) & $6.768 \mathrm{a}$ & $25.823 \mathrm{a}$ & $65.457 \mathrm{a}$ & $35.906 \mathrm{a}$ & $5.209 \mathrm{a}$ & $33.832 \mathrm{a}$ & $78.329 \mathrm{a}$ & $39.902 \mathrm{a}$ \\
\hline \multirow{3}{*}{$\begin{array}{l}\text { Volume } \\
\mathrm{cm}^{3}\end{array}$} & no-tillage (NT) & $0.177 \mathrm{a}$ & $1.307 \mathrm{a}$ & $3.430 \mathrm{a}$ & $1.805 \mathrm{a}$ & $0.076 \mathrm{~b}$ & $1.508 \mathrm{~b}$ & $2.882 \mathrm{a}$ & $1.519 \mathrm{~b}$ \\
\hline & $\begin{array}{l}\text { conventional } \\
\text { tillage (CT) }\end{array}$ & $0.200 \mathrm{a}$ & $1.491 \mathrm{a}$ & $2.957 \mathrm{~b}$ & $1.339 \mathrm{~b}$ & $0.091 \mathrm{ab}$ & $1.595 \mathrm{a}$ & $2.726 \mathrm{a}$ & $1.620 \mathrm{~b}$ \\
\hline & deep tillage (DT) & $0.240 \mathrm{a}$ & $1.601 \mathrm{a}$ & $3.454 \mathrm{a}$ & $1.938 \mathrm{a}$ & $0.113 \mathrm{a}$ & $1.627 \mathrm{a}$ & $3.051 \mathrm{a}$ & $2.137 \mathrm{a}$ \\
\hline \multirow{3}{*}{$\begin{array}{l}\text { Average } \\
\text { diameter } \\
\mathrm{mm}\end{array}$} & no-tillage (NT) & $0.459 \mathrm{~b}$ & $0.591 \mathrm{~b}$ & $0.616 \mathrm{a}$ & $0.589 \mathrm{a}$ & $0.447 \mathrm{~b}$ & $0.733 \mathrm{a}$ & $0.681 \mathrm{a}$ & $0.610 \mathrm{a}$ \\
\hline & $\begin{array}{l}\text { conventional } \\
\text { tillage (CT) }\end{array}$ & $0.555 \mathrm{a}$ & $0.790 \mathrm{a}$ & $0.642 \mathrm{a}$ & $0.546 \mathrm{a}$ & $0.556 \mathrm{a}$ & $0.737 \mathrm{a}$ & $0.671 \mathrm{a}$ & $0.589 \mathrm{a}$ \\
\hline & deep tillage (DT) & $0.568 \mathrm{a}$ & $0.805 \mathrm{a}$ & $0.695 \mathrm{a}$ & $0.599 \mathrm{a}$ & $0.582 \mathrm{a}$ & $0.745 \mathrm{a}$ & $0.691 \mathrm{a}$ & $0.615 \mathrm{a}$ \\
\hline
\end{tabular}

Significant at $P<0.05$ 
No significant difference was observed in the root volume among the three tillage methods. At the anthesis, the total root length was the largest under DT and the smallest in NT, and the root surface area and average root diameter were significantly higher under DT and CT than in NT. No significant difference was observed in the root volume among the three tillage methods. At the grain filling stage, the total root length, root surface area and root volume were significantly higher under DT and NT than in CT.

However, no significant difference was observed in the root diameter among the three tillage methods. At the mature stage, the total root length was the largest under DT and the smallest in CT. The root volume was significantly larger under DT and NT than in CT, and no significant difference was observed in the root surface area and average root diameter between the tillage methods. The total root length, root surface area, root volume and average root diameter increased initially and then decreased with the growth of Tartary buckwheat. The law of change in 2018 was similar to that in 2017.

Root activity. The root activity of Tartary buckwheat continuously decreased with the advancement of the growth period (Table 4).

Table 4. The effect of tillage methods on root activity $\left(\mu \mathrm{g}(\mathrm{g} \times \mathrm{h})^{-1} \mathrm{FW}\right)$ of Tartary buckwheat at days after anthesis

\begin{tabular}{cllllll}
\hline Year & \multicolumn{1}{c}{ Tillage method } & 7 days & 14 days & 21 days & 28 days & 35 days \\
\hline \multirow{2}{*}{2017} & no-tillage (NT) & $0.778 \mathrm{a}$ & $0.690 \mathrm{a}$ & $0.439 \mathrm{a}$ & $0.161 \mathrm{c}$ & $0.021 \mathrm{~b}$ \\
& conventional tillage (CT) & $0.391 \mathrm{c}$ & $0.324 \mathrm{c}$ & $0.268 \mathrm{c}$ & $0.208 \mathrm{~b}$ & $0.025 \mathrm{~b}$ \\
& deep tillage (DT) & $0.535 \mathrm{~b}$ & $0.469 \mathrm{~b}$ & $0.325 \mathrm{~b}$ & $0.276 \mathrm{a}$ & $0.032 \mathrm{a}$ \\
\hline \multirow{2}{*}{2018} & no-tillage (NT) & $0.801 \mathrm{a}$ & $0.535 \mathrm{a}$ & $0.466 \mathrm{a}$ & $0.114 \mathrm{~b}$ & $0.007 \mathrm{~b}$ \\
& conventional tillage (CT) & $0.449 \mathrm{~b}$ & $0.368 \mathrm{c}$ & $0.179 \mathrm{c}$ & $0.117 \mathrm{~b}$ & $0.008 \mathrm{~b}$ \\
& deep tillage (DT) & $0.528 \mathrm{ab}$ & $0.491 \mathrm{~b}$ & $0.369 \mathrm{~b}$ & $0.284 \mathrm{a}$ & $0.032 \mathrm{a}$ \\
\hline
\end{tabular}

Significant at $P<0.05$

At 7, 14 and 21 days after anthesis, the root activity of Tartary buckwheat was the highest under NT and the lowest in CT, and the difference among the tillage methods reached a significant level. At 28 days after anthesis, the root activity was significantly higher under DT than in NT and CT, and the root activity in NT was the lowest. The law of change in 2017 and in 2018 was similar.

Photosynthetic pigment content. The contents of chlorophyll $a$, chlorophyll $b$, total chlorophyll and carotenoids in the leaves of Tartary buckwheat in 2017 and 2018 increased initially and then decreased with the growth and reached the highest at 14 days after anthesis (Table 5).

The content of chlorophyll $a$ was the highest under DT and the lowest in CT at 7 and 14 days after anthesis. At 21 days after anthesis, the chlorophyll $a$ content was significantly lower under NT than in DT and CT. The contents of chlorophyll $b$ and total chlorophyll were significantly higher under DT than in CT and NT.

Table 5. The effect of tillage methods on photosynthetic pigments content $\left(\mathrm{mg} \mathrm{L}^{-1}\right)$ in the leaves of Tartary buckwheat at days after anthesis

\begin{tabular}{|c|c|c|c|c|c|c|c|c|c|c|c|}
\hline \multirow{2}{*}{$\begin{array}{l}\text { Photosyn- } \\
\text { thetic indices }\end{array}$} & \multirow{2}{*}{ Tillage method } & \multicolumn{5}{|c|}{2017} & \multicolumn{5}{|c|}{2018} \\
\hline & & 7 days & 14 days & 21 days & 28 days & 35 days & 7 days & 14 days & 21 days & 28 days & 35 days \\
\hline \multirow{3}{*}{$\begin{array}{c}\text { Chlorophyl } \\
a\end{array}$} & no-tillage (NT) & $18.080 \mathrm{~b}$ & $23.498 b$ & $10.068 \mathrm{c}$ & $3.008 \mathrm{c}$ & $2.730 \mathrm{~b}$ & $11.520 \mathrm{c}$ & $14.363 \mathrm{c}$ & $9.172 \mathrm{a}$ & $5.603 \mathrm{c}$ & $5.018 \mathrm{~b}$ \\
\hline & $\begin{array}{l}\text { conventional } \\
\text { tillage }(\mathrm{CT})\end{array}$ & $16.363 \mathrm{c}$ & $18.963 \mathrm{c}$ & $12.995 \mathrm{~b}$ & $10.663 \mathrm{~b}$ & $8.246 \mathrm{a}$ & $15.283 \mathrm{~b}$ & $21.210 \mathrm{~b}$ & $7.673 \mathrm{~b}$ & $7.110 \mathrm{~b}$ & $5.084 \mathrm{~b}$ \\
\hline & deep tillage (DT) & $25.245 \mathrm{a}$ & $33.270 \mathrm{a}$ & $19.996 \mathrm{a}$ & $12.382 \mathrm{a}$ & $7.396 \mathrm{a}$ & $20.938 \mathrm{a}$ & $23.025 \mathrm{a}$ & $9.617 \mathrm{a}$ & $8.261 \mathrm{a}$ & $7.806 \mathrm{a}$ \\
\hline \multirow{3}{*}{$\begin{array}{c}\text { Chlorophyl } \\
b\end{array}$} & no-tillage (NT) & $7.805 \mathrm{~b}$ & $8.243 \mathrm{~b}$ & $6.953 \mathrm{a}$ & $4.058 \mathrm{~b}$ & $3.810 \mathrm{ab}$ & $3.820 \mathrm{c}$ & $5.255 \mathrm{~b}$ & $3.873 \mathrm{~b}$ & $2.995 \mathrm{~b}$ & $2.190 \mathrm{~b}$ \\
\hline & $\begin{array}{l}\text { conventional } \\
\text { tillage }(\mathrm{CT})\end{array}$ & $6.110 \mathrm{c}$ & $7.290 \mathrm{c}$ & $4.658 \mathrm{~b}$ & $4.173 \mathrm{~b}$ & $3.093 \mathrm{~b}$ & $6.748 \mathrm{~b}$ & $8.988 \mathrm{a}$ & $4.080 \mathrm{ab}$ & $3.185 \mathrm{~b}$ & $2.708 \mathrm{~b}$ \\
\hline & deep tillage (DT) & $10.757 \mathrm{a}$ & $13.500 \mathrm{a}$ & $7.975 \mathrm{a}$ & $5.218 \mathrm{a}$ & $4.178 \mathrm{a}$ & $7.880 \mathrm{a}$ & $8.923 \mathrm{a}$ & $4.723 \mathrm{a}$ & $4.418 \mathrm{a}$ & $3.903 \mathrm{a}$ \\
\hline \multirow{3}{*}{$\begin{array}{c}\text { Total } \\
\text { chlorphyl } \\
(a+b)\end{array}$} & no-tillage (NT) & $25.885 \mathrm{~b}$ & $31.741 \mathrm{~b}$ & $17.021 \mathrm{~b}$ & $7.066 \mathrm{c}$ & $6.540 \mathrm{~b}$ & $15.340 \mathrm{c}$ & $19.618 \mathrm{~b}$ & $13.045 \mathrm{a}$ & $8.598 \mathrm{c}$ & $7.208 \mathrm{~b}$ \\
\hline & $\begin{array}{l}\text { conventional } \\
\text { tillage }(\mathrm{CT})\end{array}$ & $22.473 \mathrm{~b}$ & $26.253 \mathrm{c}$ & $17.653 \mathrm{~b}$ & $14.836 \mathrm{~b}$ & $11.339 \mathrm{a}$ & $22.031 \mathrm{~b}$ & $30.198 \mathrm{a}$ & $11.753 \mathrm{~b}$ & $10.295 \mathrm{~b}$ & $7.792 \mathrm{~b}$ \\
\hline & deep tillage (DT) & $36.002 \mathrm{a}$ & $46.770 \mathrm{a}$ & $27.971 \mathrm{a}$ & $17.600 \mathrm{a}$ & $11.574 \mathrm{a}$ & $28.818 \mathrm{a}$ & $31.948 \mathrm{a}$ & $14.340 \mathrm{a}$ & $12.679 \mathrm{a}$ & $11.709 \mathrm{a}$ \\
\hline \multirow{3}{*}{ Carotenoids } & no-tillage (NT) & $25.886 \mathrm{~b}$ & $33.085 b$ & $15.092 \mathrm{c}$ & $7.280 \mathrm{c}$ & $3.539 \mathrm{~b}$ & $16.241 \mathrm{c}$ & $19.618 \mathrm{c}$ & $11.546 \mathrm{c}$ & $10.105 \mathrm{~b}$ & $7.273 \mathrm{~b}$ \\
\hline & $\begin{array}{l}\text { conventional } \\
\text { tillage }(\mathrm{CT})\end{array}$ & $22.472 \mathrm{c}$ & $26.251 \mathrm{c}$ & $18.651 \mathrm{~b}$ & $14.835 \mathrm{~b}$ & $10.614 \mathrm{a}$ & $22.03 \mathrm{lb}$ & $29.867 \mathrm{~b}$ & $12.152 \mathrm{~b}$ & $7.787 \mathrm{c}$ & $6.726 \mathrm{c}$ \\
\hline & deep tillage (DT) & $35.821 \mathrm{a}$ & $46.769 a$ & $27.971 \mathrm{a}$ & $16.560 \mathrm{a}$ & $11.338 \mathrm{a}$ & $28.818 \mathrm{a}$ & $31.945 \mathrm{a}$ & $14.047 \mathrm{a}$ & $12.116 \mathrm{a}$ & $11.662 \mathrm{a}$ \\
\hline
\end{tabular}

Significant at $P<0.05$ 
At 7 and 14 days after anthesis, the carotenoid content under DT was the highest, whereas that in CT was the lowest, and the difference among the tillage treatments reached a significant level. At 21 days after anthesis, the carotenoid content was significantly lower in NT than under DT and CT. The contents of chlorophyll $a$, chlorophyll $b$, total chlorophyll and carotenoids in the leaves in 2018 were higher in DT than under NT and CT and were similar to the results of 2017.
Antioxidant enzyme activity and MDA content. SOD and POD activities in the leaves increased initially and then decreased with the growth of Tartary buckwheat, and in 2017 reached the highest values at 21 days after anthesis (Table 6).

The SOD activity in 2018 reached the highest value at 14 days after anthesis, whereas the POD activity reached the highest value at 21 days after anthesis. The SOD activity in 2017 was the highest under DT and the

Table 6. The effect of tillage methods on antioxidant enzyme activity $\left(\mathrm{U} \mathrm{g} \mathrm{g}^{-1} \mathrm{FW} \mathrm{h}^{-1}\right)$ and malondialdehyde (MDA) content $\left(\mu \mathrm{mol} \mathrm{g}{ }^{-1} \mathrm{FW}\right)$ in the leaves of Tartary buckwheat at days after anthesis

\begin{tabular}{|c|c|c|c|c|c|c|c|c|c|c|c|}
\hline \multirow{2}{*}{$\begin{array}{l}\text { Antioxidant } \\
\text { indices }\end{array}$} & \multirow{2}{*}{ Tillage method } & \multicolumn{5}{|c|}{2017} & \multicolumn{5}{|c|}{2018} \\
\hline & & 7 days & 14 days & 21 days & 28 days & 35 days & 7 days & 14 days & 21 days & 28 days & 35 days \\
\hline \multirow{3}{*}{$\begin{array}{l}\text { Superoxide } \\
\text { dismutase } \\
\text { (SOD) }\end{array}$} & no-tillage (NT) & $6.34 \mathrm{c}$ & $8.86 \mathrm{~b}$ & $14.50 \mathrm{c}$ & $5.24 \mathrm{~b}$ & $4.49 \mathrm{~b}$ & & & $10.95 \mathrm{~b}$ & $3.98 \mathrm{~b}$ & $1.41 \mathrm{~b}$ \\
\hline & $\begin{array}{l}\text { conventional } \\
\text { tillage }(\mathrm{CT})\end{array}$ & $9.76 \mathrm{~b}$ & $12.37 \mathrm{a}$ & $16.26 \mathrm{~b}$ & $7.36 \mathrm{ab}$ & $4.70 \mathrm{~b}$ & $6.52 \mathrm{~b}$ & $18.78 \mathrm{~b}$ & $13.80 \mathrm{a}$ & $4.00 \mathrm{~b}$ & $1.93 \mathrm{~b}$ \\
\hline & deep tillage (DT) & $13.73 \mathrm{a}$ & $15.35 \mathrm{a}$ & $18.90 \mathrm{a}$ & $7.58 \mathrm{a}$ & $5.67 \mathrm{a}$ & $8.66 \mathrm{a}$ & $20.97 \mathrm{a}$ & $14.95 \mathrm{a}$ & $7.17 \mathrm{a}$ & $4.61 \mathrm{a}$ \\
\hline \multirow{3}{*}{$\begin{array}{l}\text { Peroxidase } \\
\text { (POD) }\end{array}$} & no-tillage (NT) & $77.25 \mathrm{c}$ & $104.24 \mathrm{~b}$ & $213.25 \mathrm{~b}$ & $193.68 \mathrm{c}$ & $189.31 \mathrm{c}$ & $151.68 \mathrm{~b}$ & $185.63 \mathrm{c}$ & $276.72 \mathrm{~b}$ & $235.41 \mathrm{c}$ & $208.69 \mathrm{c}$ \\
\hline & $\begin{array}{l}\text { conventional } \\
\text { tillage }(\mathrm{CT})\end{array}$ & $105.79 \mathrm{~b}$ & $192.43 \mathrm{a}$ & $262.56 \mathrm{a}$ & $230.80 \mathrm{~b}$ & $200.00 \mathrm{~b}$ & & $239.44 \mathrm{~b}$ & $275.84 \mathrm{~b}$ & $262.69 \mathrm{~b}$ & 249.48 \\
\hline & deep tillage (DT) & $162.08 \mathrm{a}$ & $204.05 \mathrm{a}$ & $278.69 \mathrm{a}$ & $253.89 \mathrm{a}$ & $236.37 \mathrm{a}$ & $184.72 \mathrm{a}$ & $256.32 \mathrm{a}$ & $284.99 \mathrm{a}$ & $285.71 \mathrm{a}$ & $263.81 \mathrm{a}$ \\
\hline \multirow{3}{*}{ MDA } & no-tillage (NT) & $0.091 \mathrm{a}$ & $0.155 \mathrm{a}$ & $0.162 \mathrm{a}$ & $0.265 \mathrm{a}$ & $0.322 \mathrm{a}$ & $0.106 \mathrm{a}$ & $0.163 \mathrm{a}$ & $0.219 \mathrm{a}$ & $0.276 \mathrm{a}$ & $0.342 \mathrm{a}$ \\
\hline & $\begin{array}{l}\text { conventional } \\
\text { tillage }(\mathrm{CT})\end{array}$ & $0.067 \mathrm{~b}$ & $0.139 \mathrm{~b}$ & $0.148 \mathrm{~b}$ & $0.190 \mathrm{~b}$ & $0.201 \mathrm{~b}$ & $0.075 \mathrm{~b}$ & $0.123 \mathrm{~b}$ & $0.173 \mathrm{~b}$ & $0.196 \mathrm{~b}$ & $0.215 b$ \\
\hline & deep tillage (DT) & $0.066 \mathrm{~b}$ & $0.110 \mathrm{~b}$ & $0.120 \mathrm{c}$ & $0.134 \mathrm{c}$ & $0.161 \mathrm{c}$ & $0.070 \mathrm{~b}$ & $0.112 b$ & $0.127 \mathrm{c}$ & $0.135 \mathrm{c}$ & $0.162 \mathrm{c}$ \\
\hline
\end{tabular}

Significant at $P<0.05$

lowest in NT. The POD activity in 2017 was the highest under DT and the lowest in NT at 7, 28 and 35 days after anthesis. At 14 and 21 days after anthesis, the POD activity was significantly higher under DT and CT than in NT. The SOD and POD activities in the leaves in 2018 were higher under DT than in NT and CT and similar to the results of 2017.

The MDA content in the leaves of Tartary buckwheat continuously increased with the growth and reached the highest values at 35 days after anthesis. At 7 and 14 days after anthesis, the MDA content was significantly higher in NT than under CT and DT. At 21, 28 and 35 days after anthesis, the MDA content in leaves was the highest in NT and the lowest under DT. The law of change in 2017 and in 2018 was similar.
Agronomic traits and yield. The plant height of Tartary buckwheat in 2017 was significantly higher under DT and CT than in NT, and in 2018 it was the largest under DT and the smallest in CT (Table 7). The number of main stem nodes was the largest under DT and the smallest in CT. The number of main stem branches in 2017 was significantly higher under DT and NT than in CT, whereas under CT and DT it was significantly higher than that in NT in 2018. The number of grains per plant in 2017 and 2018 under DT was the largest and the smallest in $\mathrm{CT}$, and the difference among the treatments reached a significant level. The grain weight per plant, 1000-grain weight and yield in 2017 and 2018 were the largest under DT and the smallest in NT. Significant differences were observed among the treatments, in which the yield under DT was approximately twice that in NT.

Table 7. The effect of tillage methods on agronomic traits and yield of Tartary buckwheat

\begin{tabular}{llccccccc}
\hline Year & \multicolumn{1}{c}{ Tillage method } & $\begin{array}{c}\text { Plant height } \\
\mathrm{cm}\end{array}$ & $\begin{array}{c}\text { Number of } \\
\text { main stem } \\
\text { nodes }\end{array}$ & $\begin{array}{c}\text { Number of } \\
\text { main stem } \\
\text { branches }\end{array}$ & $\begin{array}{c}\text { Number of } \\
\text { grains per } \\
\text { plant }\end{array}$ & $\begin{array}{c}\text { Grain } \\
\text { weight per } \\
\text { plant g }\end{array}$ & $\begin{array}{c}\text { 1000-grain } \\
\text { weight } \\
\mathrm{g}\end{array}$ & $\begin{array}{c}\text { Yield } \\
\mathrm{kg} \mathrm{ha}^{-1}\end{array}$ \\
\hline \multirow{2}{*}{2017} & $\begin{array}{c}139.67 \mathrm{~b} \\
\text { no-tillage (NT) }\end{array}$ & $15.00 \mathrm{~b}$ & $9.33 \mathrm{a}$ & $463.21 \mathrm{~b}$ & $12.23 \mathrm{c}$ & $21.74 \mathrm{c}$ & $837.83 \mathrm{c}$ \\
& conventional tillage (CT) & $150.83 \mathrm{a}$ & $12.31 \mathrm{c}$ & $6.67 \mathrm{~b}$ & $215.36 \mathrm{c}$ & $13.24 \mathrm{~b}$ & $25.88 \mathrm{~b}$ & $1107.03 \mathrm{~b}$ \\
& deep tillage (DT) & $156.67 \mathrm{a}$ & $18.33 \mathrm{a}$ & $10.69 \mathrm{a}$ & $517.23 \mathrm{a}$ & $15.39 \mathrm{a}$ & $31.20 \mathrm{a}$ & $1543.81 \mathrm{a}$ \\
\hline \multirow{2}{*}{2018 no-tillage (NT) } & $144.50 \mathrm{~b}$ & $16.32 \mathrm{~b}$ & $7.34 \mathrm{~b}$ & $581.13 \mathrm{~b}$ & $10.41 \mathrm{c}$ & $22.41 \mathrm{c}$ & $664.49 \mathrm{c}$ \\
& conventional tillage (CT) & $134.17 \mathrm{c}$ & $16.06 \mathrm{~b}$ & $10.32 \mathrm{a}$ & $527.67 \mathrm{c}$ & $13.31 \mathrm{~b}$ & $26.945 \mathrm{~b}$ & $859.16 \mathrm{~b}$ \\
& deep tillage (DT) & $159.60 \mathrm{a}$ & $19.00 \mathrm{a}$ & $9.52 \mathrm{ab}$ & $602.20 \mathrm{a}$ & $16.18 \mathrm{a}$ & $33.97 \mathrm{a}$ & $1063.69 \mathrm{a}$ \\
\hline
\end{tabular}

Significant at $P<0.05$ 


\section{Discussion}

The growth curve of Richards' equation was used to fit the grain filling of Tartary buckwheat under different tillage methods. The variation range of the shape parameter $(N)$ value under three tillage methods was $0.001113-0.001139$, which was less than 1 , and the growth curve was on the left side. This finding indicated that the filling material of Tartary buckwheat is relatively adequate, and grain growth rates are rapid in the early stage of grain filling and subsequently decrease (Zhang et al., 2020). In the present study, the initial growth power $\left(R_{0}\right)$ under DT was the highest and that in NT was the lowest, thereby indicating that the grain filling of Tartary buckwheat starts early under DT, photosynthetic products are obtained, and the maximum grain filling rate $(G \max )$ is reached within a short period after anthesis.

In comparison with CT, DT can evidently improve the root length, root depth and root quantity of summer maize (Ding, Hann, 1997). In the present study, DT promoted the root growth of Tartary buckwheat; this finding is consistent with the above-mentioned results. Root activity is an important index used to measure the nutrient absorption capability of a crop root system. A strong root activity indicates that the root system has strong ability to absorb nutrients, can maintain the normal physiological function of the shoot, delay senescence, ensure sufficient grain filling and increase the yield after anthesis.

Studies have shown that DT can promote the development of the root system of dry-farming crops, expand the distribution range of the root system in the soil, improve the vitality of the root system and delay the senescence of the crops (Izumi et al., 2009). In the present study, the root activity under NT was the highest at 7, 14 and 21 days after anthesis, and under DT - at 28 and 35 days after anthesis and was consistent with the above-mentioned results.

Chlorophyll is an important and effective pigment in photosynthesis. Its content can reflect the senescence of plants and is an important factor that affects crop yield. Senescence significantly reduces the chlorophyll content in the leaves of crops, thus affecting the normal course of photosynthesis (Chen, Dong, 2016). A study found that reasonable and controlled release of urea can effectively increase chlorophyll content in summer maize leaves and delay leaf senescence ( $\mathrm{Li}$ et al., 2017).

SOD and POD activities indicate the ability of plants to resist senescence. MDA is peroxide that reacts with many kinds of cell components and seriously damages the activity of many enzymes and membrane system; the increase of its content marks the senescence of plants (Chen et al., 2018). It has been documented that senescence decreases the activity of antioxidant enzymes, such as SOD in the leaves of plants, and breaks the dynamic balance of production and elimination of reactive oxygen species, thereby resulting in the accumulation of active oxygen species (Chen, Dong, 2016). Li et al. (2010) found that an appropriate nitrogen application can increase SOD and POD activities, decrease MDA content, delay senescence and increase the yield of maize. The results of the current experiment showed that DT can improve the chlorophyll content, the SOD and POD activities and reduce the MDA content, thus delaying the senescence of Tartary buckwheat.

DT is conducive to improving crop yield (Linh et al., 2015). Similar results were obtained in this experiment, which may be due to the change in the water and thermal environments of the soil under DT. These changes are conducive to absorbing considerable water and nutrients through the root system, promoting the growth of Tartary buckwheat root system and delaying the senescence of aboveground and underground organs, resulting in an increase in yield (Zhang et al., 2020).

\section{Conclusions}

1. A significant difference was observed in senescence and grain filling of Tartary buckwheat among the tillage methods tested: no-tillage (NT), conventional tillage (CT) and deep tillage (DT).

2. The grains filled at a faster rate and showed a larger grain weight under deep tillage than no-tillage and conventional tillage.

3. Delay of the senescence of Tartary buckwheat under deep tillage occurred mainly due to the highest values of root morphological characteristics, root activity, photosynthetic pigment contents, antioxidant enzyme activities and the lowest malondialdehyde (MDA) content.

\section{Acknowledgments}

We acknowledge the support of Joint Project of Natural Science Foundation of China and Guizhou Provincial Government Karst Science Research Center (U1812401), National Science Foundation of China (31560358), the Science and Technology Support Plan of Guizhou province, China (QianKeHeZhiCheng [2018]2297, [2019]2297 and [2020]1Y048), the Major Research Projects of Innovation Groups of Guizhou province, China (QianJiaoHe KY Zi [2017]033 and [2018]015), and the science and technology projects of Guiyang, China (ZhukeHetong [2019]11-6).

Received 28032020

Accepted 30072020

\section{References}

1. Ahmed A., Khalid N., Ahmad A., Abbasi N. A., Latif M. S.Z., Randhawa M. A. 2014. Phytochemicals and biofunctional properties of buckwheat: a review. The Journal of Agricultural, 152 (3): 349-369. https://doi.org/10.1017/S0021859613000166

2. Arduini I., Masoni A., Mariotti M. 2016. A growth scale for the phasic development of common buckwheat. Acta Agriculturae Scandinavica, Section B: Soil and Plant Science, 66 (3): 215-228. https://doi.org/10.1080/09064710.2015.1087587 
3. Chen Y. Z., Dong H. Z. 2016. Mechanisms and regulation of senescence and maturity performance in cotton. Field Crops Research, 189: 1-9. https://doi.org/10.1016/j.fcr.2016.02.003

4. Chen Y. Z., Kong X. Q., Dong H. Z. 2018. Removal of early fruiting branches impacts leaf senescence and yield by altering the sink/source ratio of field-grown cotton. Field Crops Research, 216: 10-21. https://doi.org/10.1016/j.fcr.2017.11.002

5. Ding K. L., Hann M. J. 1997. Effects of deep pine tillage on soil moisture physical characteristics and crop growth. China Rural Water and Hydropower, 11: 13-16 (in Chinese).

6. Dziedzic K., Górecka D., Kucharska M., Przybylska B. 2012. Influence of technological process during buckwheat groats production on dietary fibre content and sorption of bile acids. Food Research International, 47 (2): 279-283. https://doi.org/10.1016/j.foodres.2011.07.020

7. Giménez-Bastida J. A., Piskuła M. K., Zieliński H. 2015. Recent advances in processing and development of buckwheat derived bakery and non-bakery products a review. Polish Journal of Food Nutrition Sciences, 65 (1): 9-20. https://doi.org/10.1515/pjfns-2015-0005

8. Górecka D., Dziedzic K., Hęś M. 2014. A characteristic of dietary fiber in barley and buckwheat groats and its bile acids. Italian Journal of Food Science, 26 (1): 103-108. http://www.chiriottieditori.it/images/stories/IJFS\%20archivio/ IJFS261.pdf

9. Guglielmini A. C., Forcat J. I., Miralles D. J. 2019. The critical period for yield determination in common buckwheat (Fagopyrum esculentum Moench). European Journal of Agronomy, 110: 10-16. https://doi.org/10.1016/j.eja.2019.125933

10. Izumi Y., Yoshida T., Iijima M. 2009. Effects of sub soiling to the non-tilled field of wheat-soybean rotation on the root system development, water uptake, and yield. Plant Production Science, 12 (3): 327-335. https://doi.org/10.1626/pps.12.327

11. Kalinova J., Dadakova E. 2013. Influence of sowing date and stand density on rutin level in buckwheat. Cereal Research Communications, 41 (2): 348-358. https://doi.org/10.1556/CRC.2012.0039

12. Kreft I., Zhou M.L., Golob A., Germ M., Likar M., Dziedzic K., Luthar Z. 2020. Breeding buckwheat for nutritional quality. Breeding Science, 70 (1): 67-73. https://doi.org/10.1270/jsbbs.19016

13. Kong L., Si J., Sun M., Feng B., Zhang B., Li S., Wang Z., Wang F. 2013. Deep roots are pivotal for regulating postanthesis leaf senescence in wheat (Triticum aestivum L.). Journal of Agronomy Crop Science, 199: 209-216. https://doi.org/10.1111/jac.12007

14. Li P. Y., Yin F., Wang J. Z., Fu G. Z. 2010. The influence of nitrogen application rates and deferred applying on leaf senescence physiology in maize (Zea mays L.). Journal of Henan Agricultural Sciences, 10: 26-29 (in Chinese).

15. Li G. H., Liu P. P., Zhao B., Dong S. T., Liu P., Zhang J. W., Tian C. X., He Z. J. 2017. Effects of water conditions and controlled release urea on yield and leaf senescence physiological characteristics in summer maize. Chinese Journal of Applied Ecology, 28 (2): 517-580 (in Chinese).

16. Liang C. G., Song Y. X., Guo X., Kong D. Z., Wang Y., Zhao Q., Huang K. F. 2016. Characteristics of the grainfilling process and starch accumulation of high-yield common buckwheat 'cv. Fengtian 1' and Tartary buckwheat 'cv. Jingqiao 2'. Cereal Research Communication, 44 (3): 393-403.

https://doi.org/10.1556/0806.44.2016.005
17. Linh T. B., Sleutel S., Guong V. T., Khoa L. V., Cornelis W. M. 2015. Deeper tillage and root growth in annual rice-upland cropping systems result in improved rice yield and economic profit relative to rice monoculture. Soil and Tillage Research, 154: 44-52. https://doi.org/10.1016/j.still.2015.06.011

18. Panda B. B., Sekhar S., Dash S. K., Behera L., Shaw B. P. 2018. Biochemical and molecular characterization of exogenous cytokinin application on grain filling in rice. BMC Plant Biology, 18: 89.

https://doi.org/10.1186/s12870-018-1279-4

19. Podolska G., Górecka D., Russel H., Dziedzic K., Boguszewska E. 2019. Abiotic stress affects the yield and nutrients of buckwheat grains. Zemdirbyste-Agriculture, 106 (3): 233-240. https://doi.org/10.13080/z-a.2019.106.030

20. Song Y. X., Guo X., Yang L. Y., Chen Q. F., Huang K. F. 2014. Effects of different NPK treatments on the yield and plumpness of Tartary buckwheat. Acta Agriculturae Zhejiangensis, 26: 1568-1572 (in Chinese).

21. Takuya K., Momo S., Ryoma T. 2019. Growth and yield response of common buckwheat (Fagopyrum esculentum Moench) to waterlogging at different vegetative stages. Plant Production Science, 22 (4): 456-464. https://doi.org/10.1080/1343943X.2019.1670682

22. Wang Y., Song Y. X., Zhang Y., Kong D. Z., Zhao Q., Lin J. Q., Huang K. F. 2017. Characteristics of starch synthesis and grain filling of common buckwheat. Journal of Cereal Science, 73: 116-121.

https://doi.org/10.1016/j.jcs.2016.12.008

23. Wang Y., Zhang Y., Li Z. Z., Zhao Q., Huang X. Y., Huang K. F. 2020. Effect of continuous cropping on the rhizosphere soil and growth of common buckwheat. Plant Production Science, 23 (1): 81-90. https://doi.org/10.1080/1343943X.2019.1685895

24. Zhang Z. L., Qu W. J. 2003. Guide of plant physiology and biochemistry experiment. Beijing, China, p. 39, 67, 123, 268, 274 (in Chinese).

25. Zhang J. H., Sui X. Z., Li B., Su B. L., Li J. M., Zhou D. X. 1998. An improved water-use efficiency for winter wheat grown under reduced irrigation. Field Crop Research, 59 (2): 91-98. https://doi.org/10.1016/S0378-4290(98)00104-X

26. Zhang W. L., Yang Q. H., Xia M. J., Bai W. M., Wang P. K., Gao X. L., Li J., Feng B. L., Gao J. F. 2019. Effects of nitrogen level on the physicochemical properties of Tartary buckwheat (Fagopyrum tataricum (L.) Gaertn.) starch. International Journal of Biological Macromolecules, 129: 799-808. https://doi.org/10.1016/j.ijbiomac.2019.02.018

27. Zhang Y., Wu X. H., Huang X. Y., He P. Y., Chen Q. F., Huang K. F. 2020. Difference of grain filling characteristics and starch synthesis between the superior and inferior spikelet of Tartary buckwheat. International Journal of Agriculture and Biology, 23 (4): 681-686.

28. Žvikas V., Pukelevičienė V., Ivanauskas L., Romanovskaja D., Jakštas V. 2016. Evaluation of phenolic antioxidant content in organically and conventionally grown buckwheat herb crop and its regrowth. Journal of the Science of Food and Agriculture, 97 (10): 3278-3283. https://doi.org/10.1002/jsfa.8176 
ISSN 1392-3196 / e-ISSN 2335-8947

Zemdirbyste-Agriculture, vol. 107, No. 4 (2020), p. 301-308

DOI 10.13080/z-a.2020.107.038

\title{
Žemès dirbimo būdų įtaka totorinių grikių augalų brendimui ir grūdų pildymuisi
}

\author{
X. Wu, Y. Zhang, P. He, X. Huang, K. Huang \\ Guizhou valstybinio universiteto Grikių auginimo technologijų tyrimo centras, Kinija
}

\section{Santrauka}

Lauko eksperimentas buvo vykdytas geltonajame priemolyje 2017 ir 2018 metais. Tirta trijų žemės dirbimo būdų: nedirbta, tradicinis dirbimas ir gilus arimas, ịtaka totorinio grikio (Fagopyrum tataricum L.) veislès 'Jinqiao 2' augalų brendimo ir grūdų pildymosi savybèms. Žemès dirbimo būdai tirti atsižvelgiant ị grikių grūdų pildymosi dinamiką, šaknų morfologijos ir fiziologijos pokyčius, fotosintezès pigmentų kiekį, fermentų antioksidacinį aktyvumą, malondialdehido (MDA) kiekị ir derlingumo formavimąsi. Pradinio augimo energija, grūdų pildymosi greitis, šaknų morfologinių savybių vertès bei aktyvumas, fotosintetinių pigmentų kiekis ir fermentų antioksidacinis aktyvumas buvo didžiausi giliai ariant. Didžiausias MDA kiekis buvo, kai dirvožemis nebuvo dirbtas. Totorinių grikių agronominès savybės ir derliaus formavimosi rodikliai buvo geresni giliai ariant.

Tyrimo rezultatai parodè, kad gilus arimas padidino totorinių grikių grūdų pildymąsi, pavèlino augalų brendimą ir padidino galutinị derlių.

Reikšminiai žodžiai: ankstyvas brendimas, derlius, gilus žemės dirbimas, grūdų pildymasis, šaknų morfologija. 